\title{
Foraging behavior of tyrant flycatchers (Aves, Tyrannidae) in Brazil
}

\author{
Vagner de A. Gabriel ${ }^{1} \&$ Marco A. Pizo ${ }^{2}$ \\ 1 Pós-Graduação em Ciências Biológicas, Área de Zoologia, Universidade Estadual Paulista. Caixa Postal 199, 13506-900 Rio \\ Claro, São Paulo, Brasil. E-mail: vagnerag@yahoo.com.br \\ 2 Programa de Pós-graduação em Biologia, Ciências da Saúde, Universidade do Vale do Rio dos Sinos. Avenida Unisinos 950, \\ 93022-000 São Leopoldo, Rio Grande do Sul, Brasil. E-mail: mapizo@unisinos.br
}

\begin{abstract}
In this paper we present data on the foraging maneuvers and substrates used to capture preys by 28 species of tyrant flycatchers (Tyrannidae) in Brazil. For six species: Arundinicola leucocephala Linnaeus, 1764, Fluvicola nengeta Linnaeus, 1766, Machetornis rixosa Vieillot, 1819, Myiozetetes similis Spix, 1825, Pitangus sulphuratus Linnaeus, 1766, and Tyrannus melancholicus Vieillot, 1819 -, we go further to investigate perch height, search time, sally distance, and sally angle. With a few exceptions, sally strike was the most frequent foraging maneuver. Living foliage and air were the most frequent substrates used to capture preys. Among the six species studied in detail we found three distinct groups of perch heights: $F$. nengeta and M. rixosa foraged on the ground, A. leucocephala with P. sulphuratus were medium-height foragers, and $T$. melancholicus and M. similis form the third group for which prey attacks usually start from perches from the ground up to $3 \mathrm{~m}$. With the exception of $P$. sulphuratus, which had the longest search time, the other five species did not differ in this aspect of the foraging behavior. Three groups were also discernible in relation to sally distance: $F$. nengeta and M. rixosa usually attacked prey close $(<2 \mathrm{~m})$ to them, A. leucocephala, P. sulphuratus and M. similis form a medium-distance (3-4 m) group, and T. melancholicus had the longest sally distances (up to $12 \mathrm{~m}$ ). Birds differ in details of the sally angle that, together with other subtle differences in the foraging behavior, may render important differences in prey selection.
\end{abstract}

KEY WORDS. Birds, feeding behavior, foraging maneuvers, prey selection.

RESUMO. Comportamento de forrageamento de tiranídeos (Aves, Tyrannidae) no Brasil. Este trabalho apresenta dados acerca do comportamento de forrageamento e substratos usados para a captura de presas por 28 espécies de tiranídeos (Tyrannidae) no Brasil. Para seis espécies: Arundinicola leucocephala Linnaeus, 1764, Fluvicola nengeta Linnaeus, 1766, Machetornis rixosa Vieillot, 1819, Myiozetetes similis Spix, 1825, Pitangus sulphuratus Linnaeus, 1766 e Tyrannus melancholicus Vieillot, 1819 -, também são apresentados dados sobre a altura do poleiro usado para caça, tempo de procura por presas, distância e ângulo de ataque. Com raras exceções, manobras do tipo "sally strike" foram as mais freqüentes, enquanto folhas vivas e o ar foram os substratos mais comumente usados para capturar presas. Para as seis espécies acima citadas três grupos de altura de forrageamento puderam ser discernidos: F. nengeta e M. rixosa forrageiam no chão, A. leucocephala e $P$. sulphuratus ocupam um estrato médio e $T$. melancholicus e M. similis formam um terceiro grupo e geralmente atacam suas presas a partir de poleiros situados a $3 \mathrm{~m}$ ou mais do chão. Com exceção de $P$. sulphuratus, que apresentou o tempo de procura mais longo, as outras cinco espécies não diferiram nesse aspecto. Três grupos foram também discernidos em relação à distância de ataque: $F$. nengeta e M. rixosa atacam presas próximas $(<2 \mathrm{~m})$ a eles, A. leucocephala, P. sulphuratus e M. similis formam um grupo de média distância (3-4 m) e T. melancholicus apresentou as mais longas distâncias de ataque (até $12 \mathrm{~m}$ ). As aves diferiram em alguns aspectos do ângulo de ataque que, juntamente com diferenças sutis em outros aspectos do comportamento de forrageamento podem levar a diferenças importantes na seleção de presas.

PALAVRAS CHAVE. Comportamento alimentar, seleção de presas.

Tyrant flycatchers form one of the most diverse bird families (Tyrannidae) in the world, comprising 429 species (DEL Hoyo et al. 2004). The diet of tyrant flycatchers is composed mainly of arthropods, although fruits and small vertebrates are also eaten at varying extents by some species (SHERRY 1984, SICK 1997, DEL
Hoyo et al. 2004). Tyrant flycatchers capture these food items in a diverse array of substrates using a variety of foraging tactics encompassing flight, perch-, and soil-based maneuvers (FitzPatrick 1980). According to FitzPATRICK (1985), the diversity of foraging modes among tyrant flycatchers is closely associ-

Revista Brasileira de Zoologia 22 (4): 1072-1077, dezembro 2005 
ated with certain morphological features (bill and wing shapes, tarsus length) and greatly contributes to niche separation, thus permitting the astonishing adaptive radiation of this family in the American continent, where it is endemic (Traylor \& FitzPATRick 1982, del Hoyo et al. 2004).

Although several aspects of the foraging behavior of tyrant flycatchers have been studied, detailed accounts are available for a low proportion of species (FitzPatrick 1981, CinTrA 1997), thus precluding extensive comparative studies. This lack of information is particularly true for species occurring exclusively in the Neotropical region. To fulfill this gap, we collected data on the foraging maneuvers and substrate used to capture preys by 28 species representing 24 genera of tyrant flycatchers in Brazil. For six of these species, Arundinicola leucocephala Linnaeus, 1764, Fluvicola nengeta Linnaeus, 1766, Machetornis rixosa Vieillot, 1819, Myiozetetes similis Spix, 1825, Pitangus sulphuratus Linnaeus, 1766, and Tyrannus melancholicus Vieillot, 1819 , including some of the most common tyrant flycatchers in Brazil-e.g. M. similis, P. sulphutaus, T. melancholichus -, we go further to investigate perch height, search time, sally distance, and sally angle (sensu Fitzpatrick 1980). The studied species included strictly forest species and species of open country, some of them endangered - e.g. Platyrinchus leucoryphus Wied, 1831 (BirdLife InTERnATIONAL 2000) - or infrequently seen - e.g. Mucipipra vetula Lichtenstein, 1823, Serpophaga nigricans Vieillot, 1817.

\section{MATERIAL AND METHODS}

\section{Study Sites}

Data were collected at six sites in Brazil: (I) Parque Estadual Intervales (hereafter PEI; $24^{\circ} 16^{\prime} \mathrm{S}, 48^{\circ} 25^{\prime} \mathrm{W}$ ) is a 49,000 -ha reserve composed of rain forest in a mosaic of successional stages. (II) Floresta Estadual "Edmundo Navarro de Andrade" (FEENA; $22^{\circ} 22^{\prime} \mathrm{S}, 47^{\circ} 33^{\prime} \mathrm{W}$ ) has 2,314 ha of Eucalyptus L'Hér., 1789 plantation with scattered patches of native, semideciduous forest. At FEENA data were collected at an urbanized area occupied by several buildings and an artificial lake. Extensive open areas formed by lawns ornamented with scattered native and exotic plants formed the bulk of the area, which was totally surrounded by Eucalyptus. (III) Mata de Santa Genebra (MSG; $22^{\circ} 49^{\prime}$ S, 47 $06^{\prime} \mathrm{W}$ ) is a 250 ha fragment of isolated, degraded semideciduous forest. (iv) Private lands located in the rural zone of Itatiba municipality (ITA; $22^{\circ} 57^{\prime} \mathrm{S}, 46^{\circ} 44^{\prime} \mathrm{W}$ ) in an area of approximately 80 ha. This region was originally covered by semideciduous forest, which was fragmented many decades ago to give place to pastures and agricultural fields. Embedded in this human-derived matrix, one can find small forest fragments (1-20 ha) in different succesional stages and marsh areas where data where collected. (v) Reserva Natural da Vale do Rio Doce (RNVRD; $19^{\circ} 12^{\prime} \mathrm{S}, 40^{\circ} 02^{\prime} \mathrm{W}$ ) is a 21,787 -ha private reserve of well-preserved rain forest. (VI) Fazenda Rio Negro (FRN; $19^{\circ} 33^{\prime} \mathrm{S}, 56^{\circ} 14^{\prime} \mathrm{W}$ ) is a 7,500-ha private ranch occupied by a natural mosaic of habitats, including old fields, cerrados, dry forests, and seasonally flooded forests (gallery forest) bordering the Rio Negro. At FRN, data were collected mainly in cerrado areas (see OlIVEIRA \& MARQUIS 2002). Sites (I) to (IV) are in the state of São Paulo, and RNVRD is located in the state of Espírito Santo, all of them in southeast Brazil under the domain of the Brazilian Atlantic Forest (sensu Morellato \& Haddad 2000). FRN is in the Pantanal region of central Brazil.

\section{Sampling protocol}

Data were collected opportunistically during several visits to the study sites carried out from 1990 to 2004 . Specifically for FEENA, where more detailed data were collected (see below), visits spanned from January to September 2001. Every time we found a foraging bird we followed it until it disappeared or changed its activity. The foraging maneuvers and the substrate where the bird captured or attempted to capture a prey were recorded. Foraging maneuvers followed the classification scheme of REMSEN \& Robinson (1990), and substrates were classified according to the following categories: air, living foliage, dead foliage, trunks or branches, ground, water, and others (rocks, flowers).

For six species: Arundinicola leucocephala, Fluvicola nengeta, Machetornis rixosa, Myiozetetes similis, Pitangus sulphuratus, and Tyrannus melancholicus, additional aspects of the foraging behavior were recorded at FEENA, including perch height (i.e., the height above ground of the perch from where the bird started a foraging maneuver), search time (the duration of each pause preceding either a foraging maneuver or a flight to a new perch), sally distance (the distance traveled between perch and prey; indicates the distance over which the birds sight prey), and sally angle (the angle above or below the horizontal followed during a sally toward a prey item; indicates directions from which prey are detected) (Fitzpatrick 1980). Perch height, sally distance and sally angle were visually estimated. For the latter variable we adopted the following angle categories to denote upward (positive angles) or downward (negative angles) sallies: $90^{\circ}$ (encompassing angles from $61^{\circ}$ to $\left.90^{\circ}\right), 60^{\circ}\left(31^{\circ}\right.$ to $\left.60^{\circ}\right), 30^{\circ}\left(1^{\circ}\right.$ to $\left.30^{\circ}\right), 0^{\circ}$ (perch level), $-30^{\circ}\left(-1^{\circ}\right.$ to $\left.-30^{\circ}\right),-60^{\circ}\left(-31^{\circ}\right.$ to $\left.-60^{\circ}\right)$, and $-90^{\circ}\left(-61^{\circ}\right.$ to $\left.-90^{\circ}\right)$. For birds foraging on the ground or on plants growing on water surface perch height was zero.

Given the non-normal distribution of the data, we used median (and quartiles) as the measure of central tendency. Interspecific comparisons were made with Kruskal-Wallis test followed by multiple comparisons, as performed by STATISTICA (version 6.0; STATSOFT 1996), when a significant difference was detected.

\section{RESULTS AND DISCUSSION}

With a few exceptions, sally strike was the most frequent foraging maneuver adopted by tyrant flycatchers (Tab. I). Only ground-foraging birds ( $F$. nengeta and $M$. rixosa) departure from this pattern, adopting glean most frequently than any other foraging maneuver. Data for $P$. sulphuratus confirmed its "supreme generalist" (in the words of FitzPATRick 1980) foraging behavior; it used seven of the nine foraging maneuvers recorded 
Table I. Frequency (\%) of foraging maneuvers used by tyrant flycatchers. Species are arranged in alphabetical order. The most frequent foraging maneuvers used by each species are highlighted.

\begin{tabular}{|c|c|c|c|c|c|c|c|c|c|c|}
\hline \multirow{2}{*}{ Species * } & \multirow{2}{*}{$\mathrm{N}$} & \multicolumn{4}{|c|}{ Sally } & \multicolumn{2}{|c|}{ Leap } & \multirow{2}{*}{ Lunge } & \multirow{2}{*}{ Glean } & \multirow{2}{*}{ Scratch } \\
\hline & & Strike & Glide & Hover & Pounce & Upward & Jownward & & & \\
\hline Arundinicola leucocephala Linnaeus, $1764^{2}$ & 439 & 96.6 & 0.0 & 1.1 & 0.0 & 0.0 & 0.0 & 0.0 & 2.3 & 0.0 \\
\hline Camptostoma obsoletum Temminck, $1824^{4}$ & 4 & 50.0 & 0.0 & 0.0 & 0.0 & 0.0 & 0.0 & 0.0 & 50.0 & 0.0 \\
\hline Elaenia flavogaster Thunberg, 1822 2,4 & 14 & 100.0 & 0.0 & 0.0 & 0.0 & 0.0 & 0.0 & 0.0 & 0.0 & 0.0 \\
\hline Fluvicola nengeta Linnaeus, $1766^{2}$ & 643 & 12.6 & 0.0 & 0.3 & 1.6 & 5.4 & 0.2 & 13.1 & 66.9 & 0.0 \\
\hline Gubernetes yetapa Vieillot, $1818^{4}$ & 7 & 100.0 & 0.0 & 0.0 & 0.0 & 0.0 & 0.0 & 0.0 & 0.0 & 0.0 \\
\hline Hemitriccus orbitatus Wied, $1831^{1}$ & 7 & 100.0 & 0.0 & 0.0 & 0.0 & 0.0 & 0.0 & 0.0 & 0.0 & 0.0 \\
\hline H. margaritaceiventer d'Orbigny \& Lafresnaye, $1837^{6}$ & 54 & 88.9 & 0.0 & 3.7 & 0.0 & 0.0 & 0.0 & 3.7 & 3.7 & 0.0 \\
\hline Lathrotriccus euleri Cabanis, $1868^{1}$ & 16 & 87.5 & 0.0 & 12.5 & 0.0 & 0.0 & 0.0 & 0.0 & 0.0 & 0.0 \\
\hline Leptopogon amaurocephalus Tschudi, 1846 1,4 & 42 & 90.5 & 0.0 & 7.1 & 0.0 & 0.0 & 0.0 & 0.0 & 2.4 & 0.0 \\
\hline Machetornis rixosa Vieillot, $1819^{2}$ & 855 & 0.9 & 0.0 & 0.0 & 0.4 & 10.4 & 0.0 & 10.3 & 77.9 & 0.1 \\
\hline Mionectes rufiventris Cabanis, $1846^{1}$ & 4 & 75.0 & 0.0 & 0.0 & 0.0 & 0.0 & 0.0 & 0.0 & 25.0 & 0.0 \\
\hline Muscipipra vetula Lichtenstein, $1823^{1}$ & 4 & 100.0 & 0.0 & 0.0 & 0.0 & 0.0 & 0.0 & 0.0 & 0.0 & 0.0 \\
\hline Myiobius barbatus Gmelin, $1789{ }^{1}$ & 24 & 95.8 & 0.0 & 4.2 & 0.0 & 0.0 & 0.0 & 0.0 & 0.0 & 0.0 \\
\hline Myiodinastes maculatus Statius Muller, $1776^{1}$ & 15 & 73.3 & 6.7 & 13.3 & 0.0 & 0.0 & 0.0 & 0.0 & 6.7 & 0.0 \\
\hline Myiornis auricularis Vieillot, $1818^{1,5}$ & 603 & 92.9 & 0.0 & 5.8 & 0.0 & 0.0 & 0.0 & 0.0 & 1.3 & 0.0 \\
\hline Myiozetetes similis Spix, $1825^{2}$ & 173 & 76.3 & 5.8 & 5.8 & 1.2 & 1.2 & 0.0 & 0.0 & 9.8 & 0.0 \\
\hline Phylloscartes oustaleti Sclater, $1877^{1}$ & 13 & 92.3 & 0.0 & 7.7 & 0.0 & 0.0 & 0.0 & 0.0 & 0.0 & 0.0 \\
\hline Pitangus sulphuratus Linnaeus, $1766^{2}$ & 127 & 47.2 & 2.4 & 2.4 & 16.5 & 3.1 & 1.6 & 0.0 & 26.8 & 0.0 \\
\hline Platyrincus leucoryphus Wied, $1831^{1}$ & 18 & 100.0 & 0.0 & 0.0 & 0.0 & 0.0 & 0.0 & 0.0 & 0.0 & 0.0 \\
\hline P. mystaceus Vieillot, $1818^{1}$ & 17 & 100.0 & 0.0 & 0.0 & 0.0 & 0.0 & 0.0 & 0.0 & 0.0 & 0.0 \\
\hline Poecilotriccus plumbeiceps Lafresnaye, $1846^{1}$ & 7 & 85.7 & 0.0 & 0.0 & 0.0 & 0.0 & 0.0 & 0.0 & 14.3 & 0.0 \\
\hline Pyrocephalus rubinus Boddaert, $1783^{6}$ & 10 & 100.0 & 0.0 & 0.0 & 0.0 & 0.0 & 0.0 & 0.0 & 0.0 & 0.0 \\
\hline Serpophaga nigricans Lichtenstein, $1823^{1}$ & 10 & 80.0 & 0.0 & 0.0 & 0.0 & 0.0 & 0.0 & 0.0 & 20.0 & 0.0 \\
\hline S. subcristata Vieillot, $1817^{2}$ & 5 & 80.0 & 0.0 & 0.0 & 0.0 & 0.0 & 0.0 & 0.0 & 20.0 & 0.0 \\
\hline Todirostrum cinereum Linnaeus, $1766^{3}$ & 34 & 55.9 & 0.0 & 44.1 & 0.0 & 0.0 & 0.0 & 0.0 & 0.0 & 0.0 \\
\hline T. poliocephalum Wied, $1831^{1}$ & 8 & 87.5 & 0.0 & 0.0 & 0.0 & 0.0 & 0.0 & 0.0 & 12.5 & 0.0 \\
\hline Tolmomyas sulphurescens Spix, $1825^{1}$ & 11 & 81.8 & 0.0 & 18.2 & 0.0 & 0.0 & 0.0 & 0.0 & 0.0 & 0.0 \\
\hline Tyrannus melancholicus Vieillot, $1819^{2}$ & 196 & 71.9 & 15.3 & 8.2 & 4.6 & 0.0 & 0.0 & 0.0 & 0.0 & 0.0 \\
\hline
\end{tabular}

* Numbers following each species refer to sites where data were collected: (1) PEI, (2) FEENA, (3) MSG, (4) ITA, (5) RFCVRD, (6) FRN. See text for site descriptions.

for all species included in this study. In addition to P. sulphuratus, F. nengeta, M. rixosa, and M. similis also used a variety of maneuvers to gather food (Tab. I).

Living foliage and air were the most frequent substrates were tyrant flycatchers captured or attempted to capture preys (Tab. II). Arundinicola leucocephala, a marsh bird, was the only exception, capturing preys most frequently on the water surface. Gubernetes yetapa Vieillot, 1818, another marsh bird, usually perch on marsh plants to attack preys located on the ground immediately below. The frequency of use of water and ground as foraging substrates for A. leucocephala and G. yetapa, respectively, may be largely a result of the matrixes surrounding the marshes where these species were studied, a lake in the case of A. leucocephala, and pasture for G. yetapa. Perched on plants located at the border of their marshes, these birds looked down to find prey in the surrounding water or pasture. As noted elsewhere (DEL Hoyo et al. 2004), and contrary to Formicariids, dead leaves were rarely a foraging substrate for tyrant flycatchers. Only the two predominantly ground-foraging species, $F$. nengeta and $M$. rixosa, occasionally scratch dead leaves on the ground while looking for preys. Preys spotted by Serpophaga nigricans were frequently on the rocks standing along the rivers and streams that form the habitat for this species. Once again, $P$. sulphuratus, F. nengeta, M. rixosa, and M. similis were among the most generalist birds in terms of substrates used (Tab. II).

Among the six species studied in detail we found three distinct groups of perch heights: F. nengeta and M. rixosa foraged on the ground, although they may occasionally attack 
Table II. Frequency (\%) of foraging substrates used by tyrant flycatchers. Species are arranged in alphabetical order. Sites where data were collected for each species are in table I. The most frequent substrates used by each species are highlighted.

\begin{tabular}{|c|c|c|c|c|c|c|c|c|}
\hline Species & $\mathrm{N}$ & Air & Live leaf & Dead leaf & Branch & Ground & Water & Others \\
\hline Arundinicola leucocephala & 439 & 37.4 & 22.8 & 0.0 & 0.9 & 0.0 & 39.0 & 0.0 \\
\hline Camptostoma obsoletum & 4 & 25.0 & 75.0 & 0.0 & 0.0 & 0.0 & 0.0 & 0.0 \\
\hline Elaenia flavogaster & 14 & 85.7 & 14.3 & 0.0 & 0.0 & 0.0 & 0.0 & 0.0 \\
\hline Fluvicola nengeta & 639 & 23.6 & 65.9 & 2.2 & 0.3 & 4.7 & 2.7 & 0.6 \\
\hline Gubernetes yetapa & 7 & 42.8 & 28.6 & 0.0 & 0.0 & 28.6 & 0.0 & 0.0 \\
\hline Hemitriccus margaritaceiventer & 7 & 100.0 & 0.0 & 0.0 & 0.0 & 0.0 & 0.0 & 0.0 \\
\hline H. orbitatus & 54 & 9.3 & 88.9 & 0.0 & 1.9 & 0.0 & 0.0 & 0.0 \\
\hline Lathrotriccus euleri & 16 & 50.0 & 43.8 & 0.0 & 6.3 & 0.0 & 0.0 & 0.0 \\
\hline Leptopogon amaurocephalus & 42 & 0.0 & 100.0 & 0.0 & 0.0 & 0.0 & 0.0 & 0.0 \\
\hline Machetornis rixosa & 813 & 16.1 & 71.8 & 4.7 & 0.1 & 7.3 & 0.0 & 0.0 \\
\hline Mionectes rufiventris & 4 & 0.0 & 75.0 & 0.0 & 25.0 & 0.0 & 0.0 & 0.0 \\
\hline Muscipipra vetula & 4 & 100.0 & 0.0 & 0.0 & 0.0 & 0.0 & 0.0 & 0.0 \\
\hline Myiobius barbatus & 24 & 29.2 & 70.8 & 0.0 & 0.0 & 0.0 & 0.0 & 0.0 \\
\hline Myiodinastes maculatus & 15 & 80.0 & 13.3 & 0.0 & 6.7 & 0.0 & 0.0 & 0.0 \\
\hline Myiornis auricularis & 603 & 8.3 & 89.4 & 0.2 & 2.2 & 0.0 & 0.0 & 0.0 \\
\hline Myiozetes similis & 173 & 82.7 & 6.9 & 0.6 & 0.6 & 8.7 & 0.6 & 0.0 \\
\hline Phylloscartes oustaleti & 13 & 38.5 & 61.5 & 0.0 & 0.0 & 0.0 & 0.0 & 0.0 \\
\hline Pitangus sulphuratus & 127 & 34.6 & 35.4 & 0.0 & 2.4 & 19.7 & 7.9 & 0.0 \\
\hline Platyrincus leucoryphus & 18 & 5.6 & 88.9 & 0.0 & 5.6 & 0.0 & 0.0 & 0.0 \\
\hline P. mystaceus & 17 & 23.5 & 76.5 & 0.0 & 0.0 & 0.0 & 0.0 & 0.0 \\
\hline Poecilotriccus plumbeiceps & 7 & 0.0 & 100.0 & 0.0 & 0.0 & 0.0 & 0.0 & 0.0 \\
\hline Pyrocephalus rubinus & 10 & 90.0 & 0.0 & 0.0 & 0.0 & 0.0 & 0.1 & 0.0 \\
\hline Serpophaga nigricans & 13 & 61.5 & 23.1 & 0.0 & 0.0 & 0.0 & 0.0 & 15.4 \\
\hline S. subcristata & 5 & 0.0 & 80.0 & 0.0 & 20.0 & 0.0 & 0.0 & 0.0 \\
\hline Todirostrum cinereum & 34 & 0.0 & 100.0 & 0.0 & 0.0 & 0.0 & 0.0 & 0.0 \\
\hline T. poliocephalum & 8 & 0.0 & 100.0 & 0.0 & 0.0 & 0.0 & 0.0 & 0.0 \\
\hline Tolmomyas sulphurescens & 11 & 0.0 & 90.9 & 0.0 & 9.1 & 0.0 & 0.0 & 0.0 \\
\hline Tyrannus melancholicus & 196 & 85.7 & 14.3 & 0.0 & 0.0 & 0.0 & 0.0 & 0.0 \\
\hline
\end{tabular}

preys while perched in herbs and shrubs; A. leucocephala used the relatively small marsh plants $(<2 \mathrm{~m})$ to attack their prey and, together with $P$. sulphuratus, forms the medium-height foragers; T. melancholicus and M. similis form the third group for which prey attacks usually started from perches located at $3 \mathrm{~m}$ from the ground or higher (Fig. 1). Although P. sulphuratus was frequently seen perched high on the vegetation, it never used such high perches for foraging (perch height range 0-9 m). Myiozetetes similis used the broader range of perch heights, from 0 to $30 \mathrm{~m}$ (Fig. 1). Given that perch height among tyrant flycatchers is largely a result of vegetation height (CINTRA 1997), it is important to note that the study site at FEENA was predominantly opened, with many scattered shrubs and small trees, which may have rendered lower foraging heights in comparison with less disturbed habitats, especially for predominantly forest species - e.g. M. similis (CINTRA 1997).
With the exception of $P$. sulphuratus, which had the longest search time (median $=134 \mathrm{~s}$, quartiles $=60-210 \mathrm{~s} ; \mathrm{H}=38,52$, $\mathrm{df}=5, \mathrm{P}<0,001)$, multiple comparisons revealed that the other five species did not differ in this aspect of the foraging behavior (Fig. 2). We noted that P. sulphuratus captured the largest preys among the six species studied in detail, which may account for its longest search time. Large preys are naturally rare, thus obliging $P$. sulphuratus to look for them for a long period of time (FITZPATRICK 1981). Although ground foragers and aerial hawkers (birds that catch flying preys) are expected to represent two extremes in the search time gradient, which reflects their respectively small and large searching radius at any one stopping point (FitZPaTRick 1980, 1981), the search times of $F$. nengeta and $M$. rixosa did not differ from $M$. similis and $T$. melancholicus. If this lack of difference is related to the structural simplicity of the vegetation at the study site that acted to 

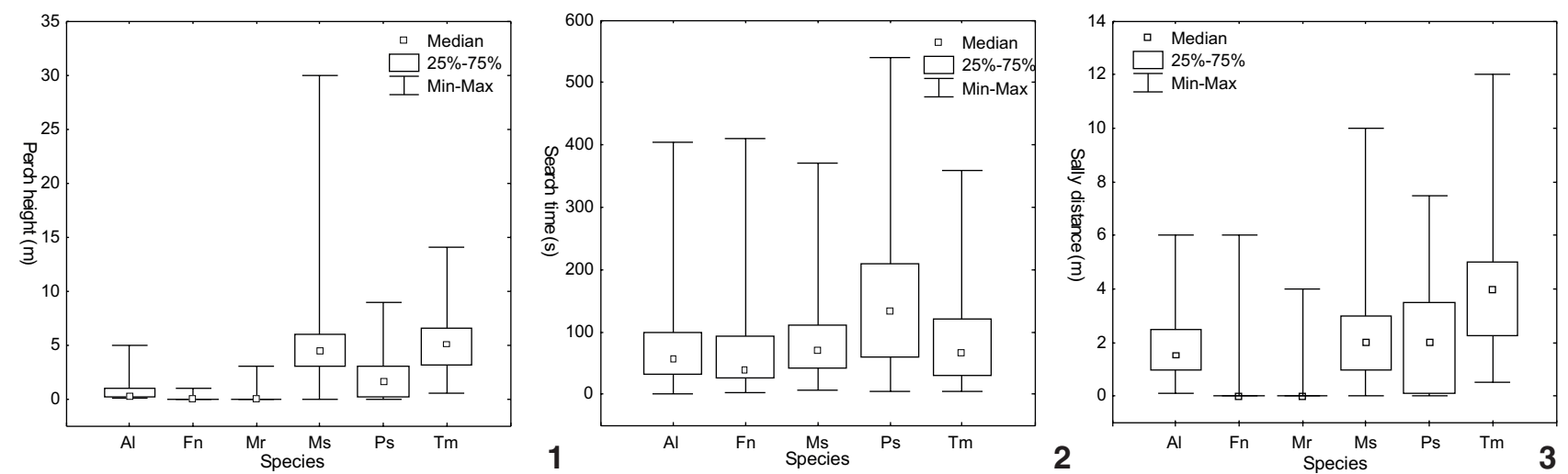

Figures 1-3. Perch heights (1), search times (2) and sally distances (3) for six species of tyrant flycatchers at Floresta Estadual "Edmundo Navarro de Andrade", Rio Claro, state of São Paulo. (Al) Arundinicola leucocephala, (Fn) Fluvicola nengeta, (Mr) Machetornis rixosa, (Ms) Myiozetetes similis, (Ps) Pitangus sulphuratus, (Tm) Tyrannus melancholicus.
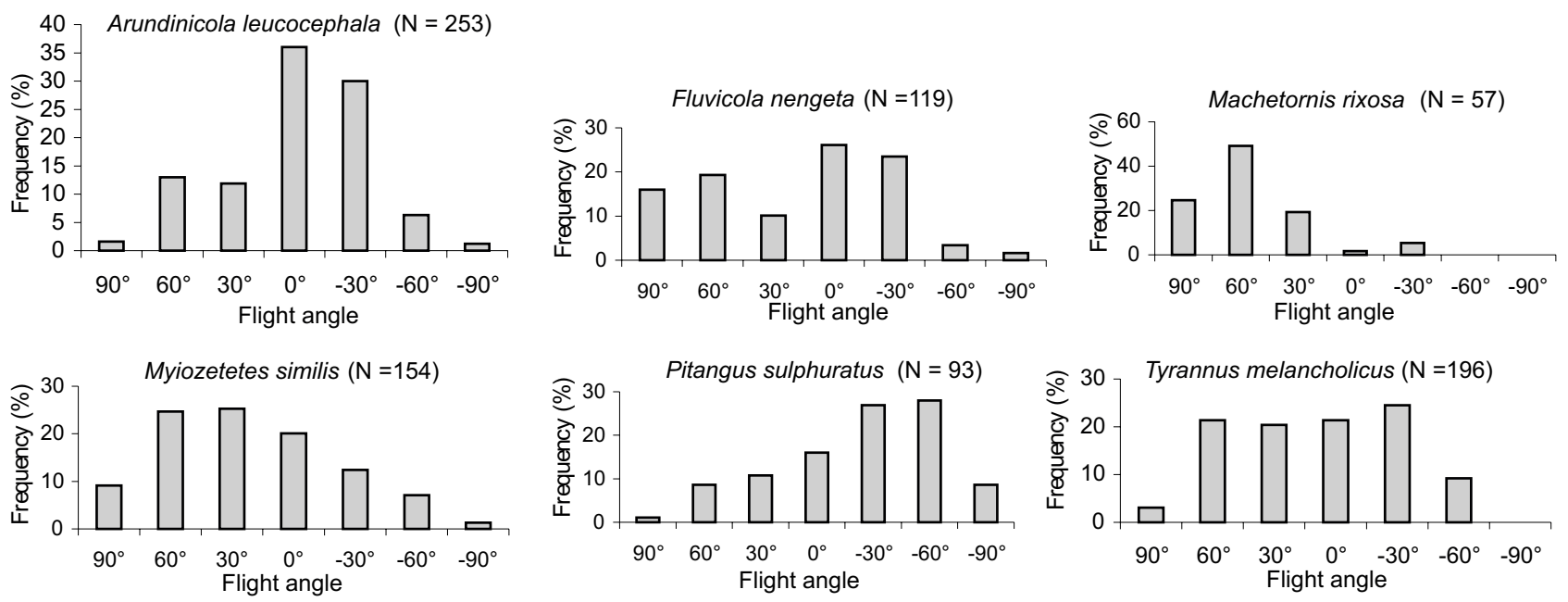

Figure 4. Sally angles for six species of tyrant flycatchers at Floresta Estadual "Edmundo Navarro de Andrade", Rio Claro, state of São Paulo. Sally angle categories are as follows: $90^{\circ}$ (from $61^{\circ}$ to $\left.90^{\circ}\right), 60^{\circ}\left(31^{\circ}\right.$ to $\left.60^{\circ}\right), 30^{\circ}\left(1^{\circ}\right.$ to $\left.30^{\circ}\right), 0^{\circ},-30^{\circ}\left(-1^{\circ}\right.$ to $\left.-30^{\circ}\right),-60^{\circ}\left(-31^{\circ}\right.$ to $\left.-60^{\circ}\right)$, and $-90^{\circ}\left(-61^{\circ}\right.$ to $\left.-90^{\circ}\right)$. Positive angles denote sallies above the perch level, while negative angles indicate sallies below the perch level. Sample sizes are indicated between parentheses. Note that scales of $Y$ axis change from one graph to another.

reduce the searching times of aerial hawkers and/or to the relative prey densities in the two substrates (ground and air) is speculative at this point.

In relation to sally distance, once again three groups are discernible: the two ground foragers, $F$. nengeta and M. rixosa, presented short distances, i.e., they usually attacked prey close $(<2 \mathrm{~m})$ to them; A. leucocephala, $P$. sulphuratus and M. similis form a medium-distance group that usually do not go beyond 3-4 $\mathrm{m}$ to attack a prey, although the latter species can go up to $10 \mathrm{~m}$ to catch a flying insect; finally T. melancholicus, which frequently attacks flying preys (Tab. II), had the longest sally distances, going up to $12 \mathrm{~m}$ from its perch to catch a prey (Fig. 3 ). The sally distance characteristic of each species largely re- flects its foraging mode. By virtue of their contrasting searching radius, ground foragers and aerial hawkers are expected to represent the lower and higher extremes of the sally distance distribution (FITZPATRICK 1980, 1981). Our results reflected this pattern, with birds using mixed foraging modes falling in between the two extremes.

Arundinicola leucocephala predominantly attacked preys that were at the same level of its perch or slightly below it (Fig. 4 ). The two ground foragers, F. nengeta and M. rixosa, slightly differ in relation to flight angle; while $F$. nengeta frequently attacked preys situated below the perch level (usually on the ground) when perched in herbs and shrubs, M. rixosa rarely did so. While on the ground, both species frequently hopped 
for preys hidden in the foliage immediately above them. Myiozetetes similis and P. sulphuratus presented opposite flight angle distributions; while $M$. similis direct its attacks to preys located above the perch level, $P$. sulphuratus usually flew down the perch to catch a prey. Tyrannus melancholicus presented an even distribution of flight angles in the range of $-30^{\circ}$ to $60^{\circ}$, rarely performing vertical flights, either above or below the perch level (Fig. 4), indicating that T. melancholicus search for their aerial preys in all directions, except vertical ones.

Although the foraging behavior of some tyrant flycatchers has been studied in detail, much has to be learnt on the peculiarities of the foraging tactics adopted by most of the species. Subtle differences emerge when we compare species with similar foraging modes. For instance, in this study the two ground foragers, $F$. nengeta and $M$. rixosa, differ in details of their foraging behavior that may render important differences in prey selection. The foraging behavior of birds is influenced by the structural complexity of the surrounding environment (Robinson \& Holmes 1982, Whelan 2001). Therefore, it is of interest to investigate the foraging behavior of birds in humanmodified habitats (like our study site at FEENA) and contrast it with more preserved environments. All of this call for more research on the foraging behavior of the ubiquitous tyrant flycatchers, a subject far from being exhausted.

\section{ACKNOWLEDMENTS}

We sincerely thank the administrations of all the parks and reserves visited during this study for making possible the data collection. This paper was prepared while MAP received a fellowship from the Brazilian Research Council (CNPq, 540481/01-7).

\section{REFERENCES}

Bird Life International. 2000. Threatened birds of the world. Barcelona, Lynx Edicions, 864p.

Cintra, R. 1997. Spatial distribution and foraging tactics of tyrant flycatchers in two habitats in the Brazilian Amazon. Studies on Neotropical Fauna and Environment, Lisse, 32 (1): 17-27

Del Hoyo, J.; A. Elliott \& D.A. Christie. 2004. Handbook of the birds of the world. Barcelona, Lynx Edicions, vol. 9, 863p.

FitzPATRICK, J.W. 1980. Foraging behavior of neotropical tyrant flycatchers. Condor, Lawrence, 82 (1): 43-57.

FitzPATRick, J.W. 1981. Search strategies of tyrant flycatchers. Animal Behavior, London, 29 (3): 810-821.

FItZPATRICK, J.W. 1985. Form, foraging behavior, and adaptive radiation in the Tyrannidae. Ornithological Monographs, Washington, 36: 447-470.

Morellato, L.P.C. \& C.F.B. Haddad. 2000. Introduction: the Brazilian Atlantic Forest. Biotropica, Lawrence, 32 (4b): 786792.

Oliveira, P.S. \& R.J. Marquis. 2002. The cerrados of Brazil: ecology and natural history of a neotropical savanna. New York, Columbia University Press, VII+398p.

Remsen, J.V. \& S.K. Robinson. 1990. A classification scheme for foraging behavior of birds in terrestrial habitats. Studies in Avian Biology, Los Angeles, 13: 144-160.

SICK, H. 1997. Ornitologia brasileira. Rio de Janeiro, Editora Nova Fronteira, 862p.

STATSOFT. 1996. Statistica for Windows: computer program manual. Tulsa, Statsoft Inc., vol. 1, 1878p.

Sherry, T.W. 1984. Comparative dietary ecology of sympatric insectivorous neotropical flycatchers. Ecological Monographs, Tempe, 54 (3): 313-338.

Robinson, S.K. \& R.T. Holmes. 1982. Foraging behavior of forest birds: the relationships among search tactics, diet, and habitat structure. Ecology, Ithaca, 63 (6): 1918-1931.

Traylor, M.A. \& J.W. Fitzpatrick. 1982. A survey of the tyrant flycatchers. The Living Bird, Ithaca, 19: 7-50.

Whelan, C.J. 2001. Foliage structure influences foraging of insectivorous forest birds: an experimental study. Ecology, Ithaca, 82 (1): 219-231.

Received in 01.IV.2005; accepted in 09.XI.2005. 